\title{
IDENTIFIKASI DINI GALUR KACANG TANAH YANG RESISTEN TERHADAP INFEKSI SCLEROTIUM ROLFSII HASIL SELEKSI IN VITRO DENGAN FILTRAT KULTUR S. ROLFSII
}

\author{
Yusnita $^{1}$, Widodo ${ }^{2}$, Rita Megia ${ }^{3}$, Hajrial Aswidinnoor' ${ }^{1}$ dan Sudarsono ${ }^{1}$
}

\begin{abstract}
Early Identification of Sclerotium rolfsii Resistant Lines of Peanut Derived from In Vitro Selection Using S. rolfsii Culture Filtrates. The objectives of this experiment was to evaluate methods for early identification of Sclerotium rolfsii resistant lines derived from fungal culture filtrate (CF)-insensitive somatic embryos (SE) and to correlate the results of early identification with that of direct $S$. rolfsii inoculation in the plastic house. In the first method, shoots regenerated from CFinsensitive SE were planted onto selective medium containing 30\% of S. rolfsii CF for one month and then responses were evaluated. In the second method, leaves and leaflets of R0 peanut lines derived from CF-insensitive SE were inoculated with $S$. rolfsii by detached leaf-dual culture test. The damages of the inoculated leaves and leaflets were assessed 6 days after inoculation. A number of R1 plants were grown in the plastic house from seeds harvested from R0 peanut lines, and they were inoculated with $S$. rolfsii at 30 days after planting (dap). Responses of the inoculated R1 plants were observed at 44 dap. Results of the experiment indicated that shoots from CF-insensitive SE showed less damage scores (DS=1.2), when cultured on CF-containing selective medium than ones from non-selected SE (DS=2.9). Most of the detached leaves and leaflets inoculated with S. rolfsii totally necrosed. However, leaves and leaflets from 7 out of 23 R0 lines showed variegation between necrosed and healthy tissues, indicating the presence of $S$. rolfsii resistant tissue among the tested leaves and leaflets. Direct inoculation of R1 plants in the plastic house showed 10 out of 18 progenies derived from 6 R0 lines showed less disease severity scores (DSS $=2$ or 3 ) and they were able to survive and produce seeds. On the other hand, seed derived (original) peanut plants cv. Kelinci inoculated with S. rolfsii all showed DSS $=5$ and died after inoculation. The overall results of the experiment indicated the usefullness of in vitro selection using $S$. rolfsii culture filtrates for regenerating S. rolfsii resistant peanut variants and the possible use of methods for early identification of desirable variants.
\end{abstract}

Key words: early identification, resistant peanut lines, in vitro selection, S. rolfsii culture filtrates.

\section{PENDAHULUAN}

Induksi keragaman somaklonal dalam kultur in vitro dan seleksi in vitro menggunakan toksin atau filtrat kultur patogen sebagai agens penyeleksi telah digunakan untuk mendapatkan plasma nutfah tanaman yang resisten terhadap patogen tanaman tertentu (Wenzel 1985, Daub 1986, Hammerschlag 1992, Jayasankar et al. 2000). Dengan seleksi in vitro, tanaman varian yang resisten terhadap penyakit telah berhasil dikembangkan, antara lain: anggur yang resisten terhadap infeksi Elsinoe ampelina (Jayasankar 2000), kedelai yang resisten terhadap infeksi Fusarium graminearum (Jin et al. 1996), dan jeruk lemon yang toleran terhadap infeksi Phoma tracheiphila (Gentile et al. 1993).

Pada kacang tanah, indikasi keberadaan variasi somaklonal di antara tanaman hasil kultur jaringan telah dilaporkan sebelumnya (Sinaga 1998). Penggunaan induksi variasi somaklonal melalui kultur kalus embriogenik jangka panjang yang dikombinasikan dengan seleksi in vitro menggunakan media selektif dengan penambahan filtrat kultur (FK)
S. rolfsii dilaporkan mampu menghasilkan embrio somatik (ES) kacang tanah yang insensitif terhadap FK S. rolfsii (Yusnita et al. 2005). Seleksi in vitro dilakukan dengan mengulturkan kalus embriogenik kacang tanah cv. Kelinci berturut-turut selama tiga periode pengulturan (masing-masing 1 bulan) di dalam medium MS (Murashige dan Skoog 1962) dengan penambahan pikloram $16 \mu \mathrm{M} \quad$ (P16) (Sulichantini 1998, Edy 1998) dengan penambahan FK S. rolfsii (Yusnita et al. 2005).

Teknik seleksi in vitro yang dikembangkan efektif menekan perkembangan kalus embriogenik, serta menekan proliferasi ES dari jaringan yang diseleksi sehingga pada akhir periode seleksi, maksimum ES yang masih berkembang dalam media selektif tinggal 5\% dibandingkan dengan media tanpa seleksi. Sejumlah ES insensitif FK S. rolfsii hasil seleksi in vitro telah berhasil diregenerasikan menjadi tunas kacang tanah generasi R0 dalam kondisi in vitro dan menjadi tanaman kacang tanah generasi R0 serta zuriatnya yang telah ditanam di rumah plastik. Salah satu syarat keberhasilan seleksi in vitro untuk resistensi terhadap penyakit tanaman adalah adanya

\footnotetext{
${ }^{1}$ Staf Lab. Biologi Molekuler Tanaman, Jurusan Budidaya Pertanian, Fak. Pertanian,Universitas Lampung,email: agrspsipb@indo.net.id

2 Dosen Departemen Proteksi Tanaman, Fakultas Pertanian Institut Pertanian Bogor

${ }^{3}$ Dosen Departemen Biologi, FMIPA, Institut Pertanian Bogor, Jl. Meranti kampus IPB Darmaga, Bogor 16680
} 
korelasi positif antara insensitivitas sel/jaringan terhadap agens penyeleksi dengan respons resistensi tanaman hasil seleksi in vitro terhadap cendawan patogen yang menjadi target. Evaluasi respons tunas R0 dalam kondisi in vitro dan tanaman kacang tanah generasi R0 yang diperoleh dari ES insensitif FK cendawan serta zuriatnya terhadap infeksi $S$. rolfsii perlu dilakukan.

Seleksi in vitro sel atau jaringan berdasarkan atas fenotipe insensitivitas di antara populasi kalus embriogenik yang sensitif terhadap FK cendawan, dengan demikian sel atau jaringan varian yang insensitif hasil seleksi in vitro diduga telah mengalami mutasi yang dikendalikan oleh gen dominan atau telah mengalami mutasi ganda (jika mutan homosigot), sehingga identitas varian dapat dievaluasi pada generasi R0.

Pengulturan tunas R0 hasil seleksi in vitro dalam media selektif MS0 yang mengandung filtrat kultur $S$. rolfsii diajukan sebagai metode identifikasi dini untuk tunas varian yang resisten terhadap S. rolfsii. Tunas $\mathrm{R} 0$ yang insensitif terhadap FK $S$. rolfsii diharapkan juga merupakan tunas yang resisten terhadap $S$. rolfsii.

Pada umumnya, evaluasi respons tanaman varian hasil seleksi in vitro terhadap infeksi cendawan target tidak dilakukan pada tanaman generasi R0, melainkan pada generasi R1 atau R2 - zuriat dari tanaman R0. Metode pengujian respons tanaman R0 terhadap S. rolfsii dapat dilakukan secara nondestruktif. Respons daun atau anak daun dari tanaman R0 yang diinokulasi $S$. rolfsii menggunakan detached leaf test dapat digunakan sebagi metode identifikasi dini tanaman varian R0 yang resisten terhadap S. rolfsii.

Jika hasil yang didapat berdasarkan dua metode deteksi dini ternyata sesuai dengan hasil evaluasi respons tanaman R1 terhadap inokulasi S. rolfsii di rumah plastik, maka metode yang dikembangkan ini dapat digunakan untuk identifikasi dini tanaman varian kacang tanah hasil selaksi in vitro yang resisten. Penelitian ini bertujuan mengevaluasi (1) respons tunas $\mathrm{R} 0$ hasil seleksi in vitro terhadap media selektif dengan penambahan FK S. rolfsii 30\%, (2) respons daun dan anak daun dari tanaman R0 hasil seleksi in vitro setelah diinokulasi dengan $S$. rolfsii menggunakan detached leaf test dalam media semi steril, dan (3) respons tanaman R1 zuriat dari tanaman R0 setelah diinokulasi pangkal batangnya dengan S. rolfsii di rumah plastik.

\section{METODE PENELITIAN}

Regenerasi Tunas dan Planlet Ro dari ES Hasil Seleksi In Vitro. Embrio somatik kacang tanah cv. Kelinci yang insensitif terhadap FK S. rolfsii telah diperoleh dari tahapan seleksi in vitro dalam penelitian sebelumnya (Yusnita et al. 2005). Setelah melalui tahapan maturasi ES dan pengecambahan dalam media MS dengan penambahan arang aktif $2 \mathrm{~g} / \mathrm{l}$ (MSAC) selama 2 bulan, ES yang berkecambah dipotong akarnya dan ditanam selama 2-3 minggu dalam medium MS dengan penambahan kombinasi BAP $2 \mathrm{mg} / \mathrm{l}$ dan kinetin $2 \mathrm{mg} / \mathrm{l}$ untuk merangsang pertumbuhan epikotil. Sebagian tunas R0 yang didapat digunakan untuk evaluasi respons tunas terhadap FK cendawan S. rolfsii.

Sebagian tunas yang lain ditanam kembali dalam media MSAC hingga berakar dan planlet yang didapat ditanam dalam pot berisi campuran pasir:arang sekam steril $(1: 1, \mathrm{v} / \mathrm{v})$, disungkup dengan plastik untuk menjaga kelembaban dan secara bertahap diaklimatisasi di rumah plastik. Tanaman R0 yang teraklimatisasi selanjutnya ditanam dalam polibeg berukuran $45 \mathrm{~cm} \mathrm{x} 45 \mathrm{~cm}$ yang berisi campuran tanah:pasir:kompos (1:1:1, v/v) dan dipelihara di rumah plastik, dibibiarkan menyerbuk sendiri dan dipelihara hingga panen untuk menghasilkan benih R0:1.

Penyiapan Filtrat Kultur S. Rolfsii. Kultur murni $S$. rolfsii yang virulen terhadap kacang tanah telah diperoleh dari penelitian sebelumnya (Yusnita et al. 2005). Isolat murni yang sama ditumbuhkan pada media potato dextrose agar (PDA), diinkubasi dalam ruang bersuhu $26^{\circ} \mathrm{C}$ selama 7 hari, dan digunakan sebagai inokulum untuk pemeliharaan isolat cendawan dan untuk pembuatan FK cendawan.

Untuk menyiapkan FK cendawan, hifa dari S. rolfsii dikulturkan dalam media MS (Murashige dan Skoog 1962), dengan penambahan komposisi vitamin B5 (Gamborg et al. 1968), sukrosa (3\%), dan agaragar $(8 \mathrm{~g} / \mathrm{l})$. Kultur cendawan diinkubasi pada ruangan bersuhu $26^{\circ} \mathrm{C}$ sampai terbentuk sclerotia (kurang lebih 14 hari) dan disterilkan menggunakan autoklaf pada suhu $121^{\circ} \mathrm{C}$, tekanan $1.5 \mathrm{~kg} / \mathrm{cm} 2$ selama 20 menit. Setelah sterilisasi, media cair yang mengandung toksin metabolit cendawan disaring untuk menghilangkan sisa-sisa hifa, dan filtratnya ditambahkan dalam medium tumbuh untuk menyeleksi tunas R0 yang diuji. 
Evaluasi respons tunas Ro terhadap filtrat kultur cendawan. Tunas R0 yang diregenerasikan dari ES hasil seleksi in vitro yang insensitif terhadap FK cendawan ditanam dalam medium MS0 dengan atau tanpa penambahan FK cendawan $30 \%$. Tunas R0 yang diregenerasikan dari ES tanpa melalui seleksi in vitro ditanam dalam medium yang sama dan digunakan sebagai pembanding.

Masing-masing sebanyak 5 tunas R0 dari ES hasil seleksi in vitro ditanam dalam medium MS0 tanpa penambahan FK dan sebanyak 20 tunas R0 ditanam dalam medium MS0 dengan penambahan FK cendawan $30 \%$. Untuk tunas R0 dari ES yang tidak melalui tahapan seleksi in vitro, masing-masing sebanayak 5 tunas ditanam dalam medium MS0 tanpa FK dan 10 tunas ditanam dalam medium dengan penambahan FK cendawan 30\%.

Respons masing-masing tunas R0 yang dievaluasi diamati setelah satu bulan dalam media selektif atau non-selektif. Gejala kerusakan tunas dievaluasi dengan menggunakan skoring antara 0 sampai 3 (Gambar 1). Tunas dengan kriteria skor 0 mempunyai fenotipe tunas sehat dan mampu berakar dalam media MS0, skor 1 姜 tunas sehat tetapi tidak berakar dalam media MS0, skor 2 姜 tunas sehat tetapi daunnya mulai menguning atau mengalami kematian, dan skor 3 羊pucuk tunas mulai mengalami kematian.
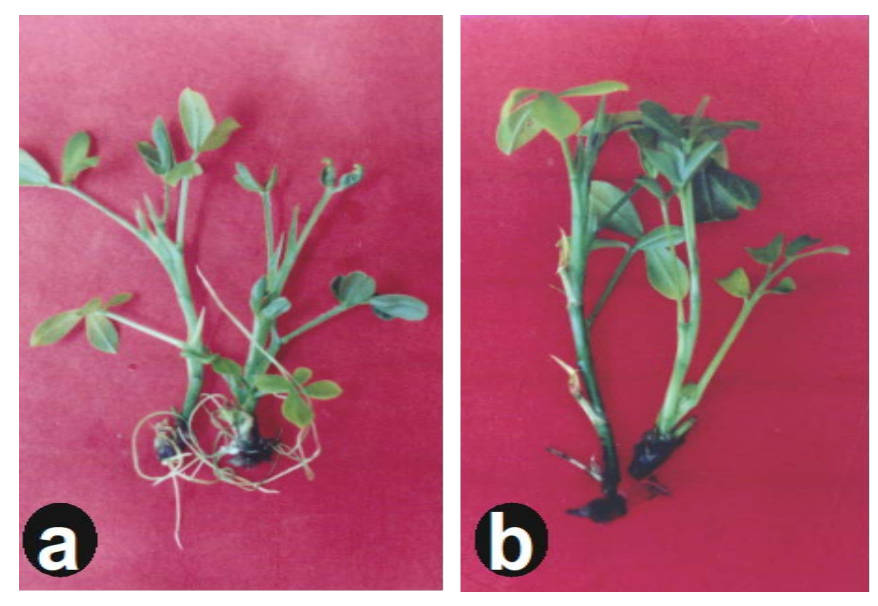

Uji Respons Tanaman R0 terhadap Infeksi S.rolfsii dengan Detached Leaf Test. Pengujian respons tanaman R0 terhadap infeksi $S$. rolfsii dilakukan secara tidak langsung menggunakan modifikasi teknik detached leaf inoculation yang dikembangkan oleh Pratt (1996). Dalam pengujian ini, daun dan anak daun tanaman kacang tanah R0 yang diregenerasikan dari ES hasil seleksi in vitro yang insensitif FK cendawan dan dari tanaman cv. Kelinci awal yang tidak melalui tahapan seleksi diinokulasi dengan menempelkan potongan hifa cendawan pada jaringan daun yang diuji. Daun dan cendawan selanjutnya ditanam dalam botol kultur berisi medium agar (8 g/l) dan diinkubasi dalam kondisi semi terang selama 6 hari. Pengamatan dilakukan terhadap persentase kerusakan jaringan anak daun akibat infeksi $S$. rolfsii dan hasilnya digunakan untuk mengidentifikasi respons masing-masing tanaman R0 terhadap infeksi S. rolfsii.

Uji Respons Tanaman R1 terhadap Infeksi S. Rolfsii. Tanaman R1 ditumbuhkan dari benih R0 yang diregenerasikan dari ES hasil seleksi in vitro yang insensitif FK cendawan. Setelah berumur 1 bulan, sejumlah tanaman R1 diinokulasi dengan $S$. rolfsii menggunakan metode inokulasi yang telah dilaporkan sebelumnya (Yusnita dan Sudarsono 2004). Masing-masing tanaman R1 yang diuji dilukai pangkal batangnya, potongan hifa $S$. rolfsii yang telah
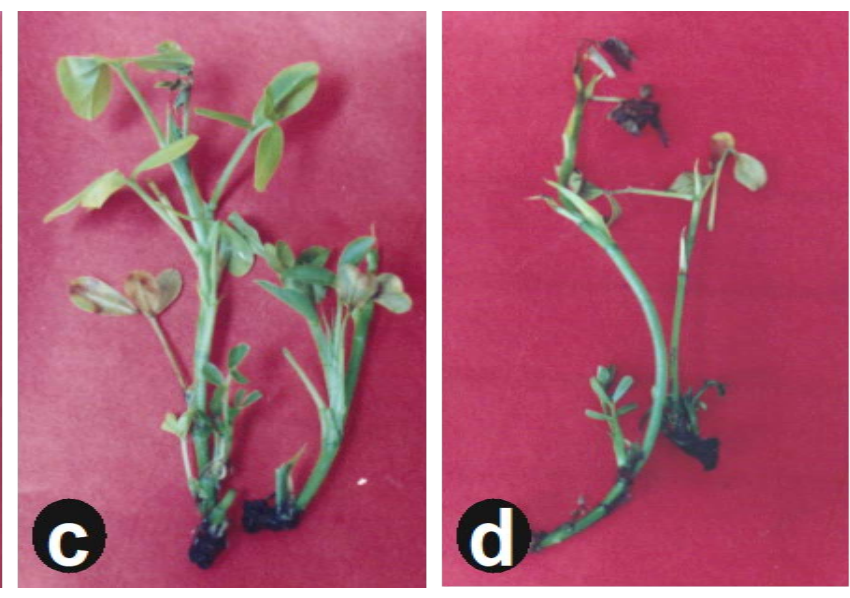

Gambar 1. Kriteria skoring gejala kerusakan tunas R0 kacang tanah setelah dikulturkan dalam medium MS0 dengan atau tanpa penambahan 30\% filtrat kultur (FK) Sclerotium rolfsii selama 1 bulan. (a) = skor 0 , tunas sehat dan mampu berakar. (b) = skor 1 , tunas sehat tetapi tidak mampu berakar. (c) = skor 2, pucuk tunas sehat dengan satu-dua daun menguning atau kering. $(\mathrm{d})=$ skor 3 , bagian pucuk tunas mati tetapi bagian pangkal masih tetap hijau 
uısıdpкalı uıteıpeıkalı paud palıgkil valdıly, udı keduanya ditimbun dengan tanah. Pengamatan gejala infeksi S. rolfsii dan kerusakan jaringan yang terjadi serta mortalitas tanaman yang diuji dilakukan dua minggu setelah inokulasi. Tingkat keparahan penyakit dievaluasi dengan skoring gejala antara 0 hingga 5 sebagaimana yang telah dilaporkan sebelumnya (Yusnita dan Sudarsono 2004). Tanaman dengan skor 0 tidak menunjukkan gejala infeksi $S$. rolfsii pada pangkal batang yang diinokulasi, skor 1 姜 mengalami nekrosis dengan luasan hingga 0.5 lingkar batang, skor 2 姜 nekrosis antara 0.5-0.75 lingkar batang, skor 3 羊 nekrosis telah melingkari batang, muncul bercak coklat yang telah meluas pada permukaan batang yang terinfeksi, skor 4 姜 seperti skor 3, batang yang terserang mulai terkulai dan sejumlah daun mulai layu, dan skor 5 姜 tanaman telah mati.

\section{HASIL}

Uji respons Tunas R0 terhadap Filtrat Kultur $S$. Rolfsii. Pengujian yang dilakukan terhadap 20 tunas R0 dalam medium selektif yang mengandung FK cendawan $30 \%$ menunjukkan tunas R0 yang diregenerasikan dari ES hasil seleksi in vitro mempunyai rataan skor kerusakan tunas $(\mathrm{SK})=1.20$ (Tabel 1). Semua tunas R0 hasil seleksi in vitro yang diuji mampu tumbuh sehat dalam medium selektif uelıgaı pelıdııvalıaı su\% in celluawall, teldpı luadk mampu berakar. Sebaliknya, tunas R0 yang diregenerasikan dari ES tanpa melalui tahapan seleksi in vitro mempunyai rataan $\mathrm{SK}=2.89$ (Tabel 1). Tunas R0 dari ES tanpa melalui seleksi in vitro yang ditanam dalam medium selektif dengan FK cendawan sebagian besar mengalami mati pucuk atau minimal menguning serta mengering.

Frekuensi dan pengelompokan tunas R0 yang diregenerasikan dari ES hasil seleksi in vitro (TC) atau tanpa seleksi in vitro (SD) dan ditanam dalam media dengan penambahan (+CF) atau tanpa penambahan (-CF) filtrat kultur cendawan berdasarkan skor kerusakan tunas disajikan pada Gambar 2.

Semua tunas R0 yang diregenerasikan dari ES dengan atau tanpa tahapan seleksi in vitro dan ditanam dalam media MS0 tanpa penambahan FK cendawan (TC-FK) atau (SD-FK) mempunyai skor kerusakan tukuensi dan pengelompokan tunas R0 dari ES taahapan seleksi in vitro dan yang ditanam dalam media selektif dengan penambahan FK cendawan $(\mathrm{SD}+\mathrm{FK})$ adalah 1 tunas $\mathrm{R} 0$ dengan $\mathrm{SK}=2$ dan 8 tunas R0 dengan $\mathrm{SK}=3$ (Gambar 2). Sebaliknya, frekuensi dan pengelompokan respons tunas R0 dari ES hasil seleksi in vitro dan ditanam dalam media selektif dengan penambahan FK cendawan (TC+FK) adalah 15 tunas R0 dengan SK=1 dan 4 tunas R0 dengan $\mathrm{SK}=2$ (Gambar 2). Contoh respons tunas R0 yang

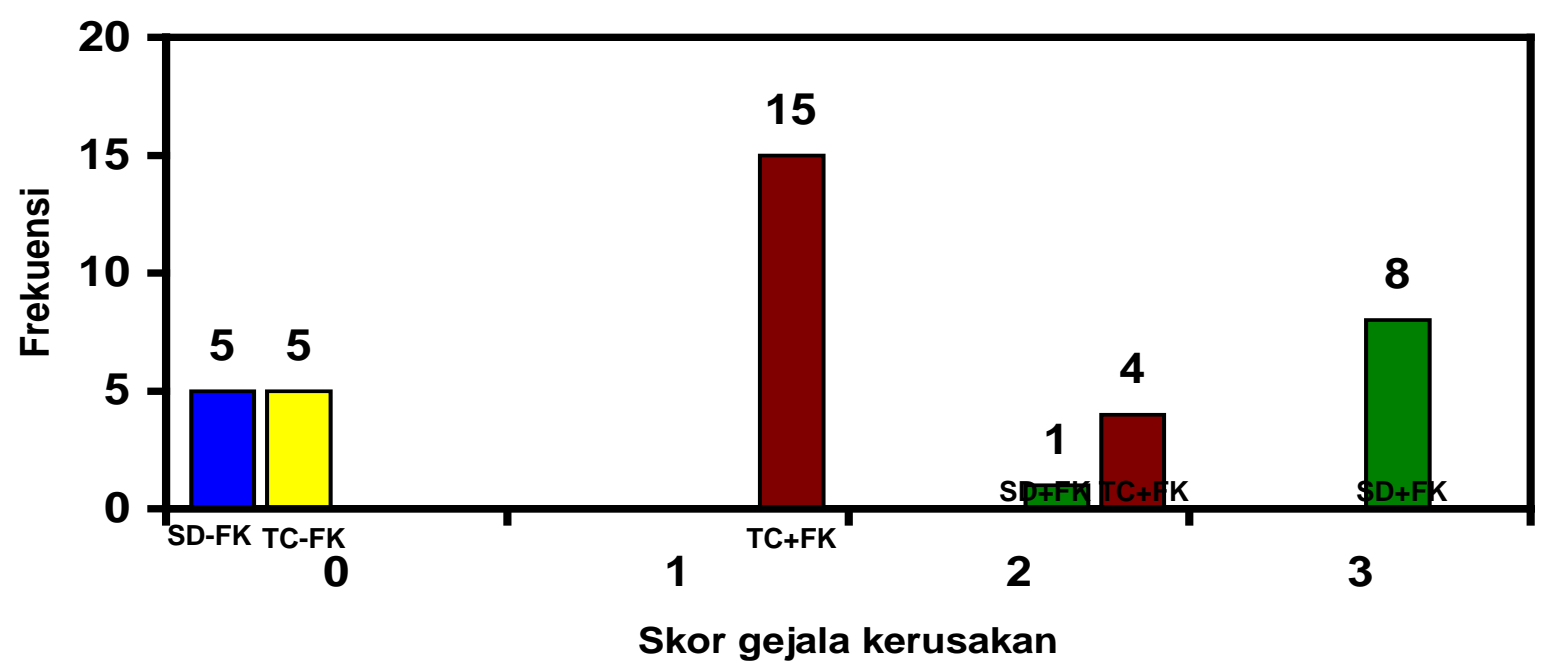

Gambar 2. Pengelompokan dan frekuensi tunas R0 yang diregenerasikan dari ES hasil seleksi in vitro yang insensitif terhadap filtrat kultur cendawan (TC) dan dari ES yang tidak melalui seleksi in vitro (SD) berdasarkan respons tingkat kerusakan tunas yang ditanam dalam media MS0 tanpa penambahan (-FK) atau dengan penambahan (+FK) filtrat kultur cendawan Sclerotium rolfsii secara in vitro 
Tabel 1. Respons tunas R0 kacang tanah cv. Kelinci hasil seleksi in vitro terhadap medium MS0 dengan penambahan 30\% filtrat kultur (FK) cendawan Sclerotium rolfsii. Pengamatan dilakukan setelah pengulturan tunas dalam media selektif selama 1 bulan.

\begin{tabular}{lccc}
\hline \multicolumn{1}{c}{$\begin{array}{c}\text { Asal tunas kacang tanah } \\
\text { yang diuji }\end{array}$} & $\begin{array}{c}\text { Media } \\
\text { tumbuh }\end{array}$ & $\begin{array}{c}\text { Jumlah tunas yang } \\
\text { diuji }\end{array}$ & $\begin{array}{c}\text { Rataan skor gejala } \\
\text { kerusakan tunas }\end{array}$ \\
\hline $\begin{array}{l}\text { Tunas hasil regenerasi dari ES } \\
\text { tanpa seleksi in vitro }\end{array}$ & MS0 & 5 & 0 \\
$\begin{array}{l}\text { MS0+30\%FK } \\
\text { insensitif FK hasil seleksi in vitro }\end{array}$ & MS0 & 9 & 2.89 \\
\hline
\end{tabular}

diregenerasikan dari ES dengan atau tanpa tahapan seleksi in vitro terhadap media selektif yang mengandung FK cendawan dapat dilihat pada Gambar 3a dan 3b.

\section{Uji Respons Tanaman Ro dengan Detached Leaf} Test. Berdasarkan hasil detached leaf test, daun dan anak daun dari tanaman R0 yang tidak melalui tahapan seleksi in vitro mengalami nekrosis $100 \%$ dan mati akibat infeksi $S$. rolfsii (Tabel 2). Hal yang sama juga diamati pada daun dan anak daun dari sebagian besar galur tanaman R0 yang diregenerasikan dari ES hasil seleksi in vitro (16 dari 23 galur R0 yang diuji). Tetapi daun dan anak daun dari 7 galur R0 yang diregenerasikan dari ES hasil seleksi in vitro (K11SC, K15 SC, K19-SC, K20-SC, K25-SC, K30-SC, dan K34-SC) menunjukkan gejala nekrosis parsial (40\% hingga $80 \%$ nekrosis) sehingga sebagian dari jaringan daun atau anak daun yang diinokulasi dengan S. rolfsii masih hijau dan tidak mati. Pada daun atau anak daun tanaman R0 tersebut, hifa cendawan berhenti tumbuh dan tidak menyebabkan kematian total dari jaringan daun atau anak daun yang diinokulasi. Contoh respons nekrosis parsial pada anak daun kacang tanah akibat infeksi $S$. rolfsii dengan detached leaf test dapat dilihat pada Gambar 4. Sedangkan persentase kerusakan daun (nekrosis) akibat infeksi $S$. rolfsii untuk masingmasing galur R0 yang diuji disajikan pada Tabel 2 . Dari 23 galur tanaman R0 hasil seleksi in vitro yang ditanam di rumah kaca dan diuji dalam percobaan ini,
7 galur tidak menghasilkan benih, dan 16 galur mampu menghasilkan sejumlah polong (Tabel 2).

Uji Respons Tanaman R1 terhadap Infeksi $S$. Rolfsii. Hasil inokulasi S. rolfsii pada masing-masing 3 tanaman R1 zuriat dari 6 galur R0 yang diregenerasikan dari ES hasil seleksi in vitro disajikan pada Tabel 3. Tiga tanaman R1 zuriat dari galur tanaman R0 nomor K3-SC, K10-SC dan K26-SC semuanya tetap hidup setelah diinokulasi dengan S. rolfsii. Tanaman R1 zuriat dari tiga galur tanaman R0 tersebut mempunyai gejala penyakit antara 2-4 (Tabel 3). Sebaliknya, tanaman R1 zuriat dari galur tanaman R0 yang lain bersegregasi antara hidup (1-2 tanaman) dan mati (1-2 tanaman) setelah diinokulasi dengan S. rolfsii. Tanaman R1 yang hidup menunjukkan skor gejala penyakit bervariasi antara 2-4.

Frekuensi dan pengelompokan tanaman R1 yang diinokulasi dengan $S$. rolfsii berdasarkan skor gejala penyakit disajikan pada Gambar 5. Semua tanaman kacang tanah cv. Kelinci awal yang tidak melalui tahapan seleksi in vitro (SD) dan diinokulasi dengan $S$. rolfsii mempunyai skor 5. Sebaliknya, untuk tanaman R1 zuriat dari 6 galur R0 hasil seleksi in vitro yang diinokulasi dengan $S$. rolfsii, frekuensi dan pengelompokan tanaman dengan skor 2 sebanyak 4 tanaman, skor 3 sebanyak 6 tanaman, skor 4 sebanyak 4 tanaman, dan skor 5 sebanyak 4 tanaman (Gambar 5). 

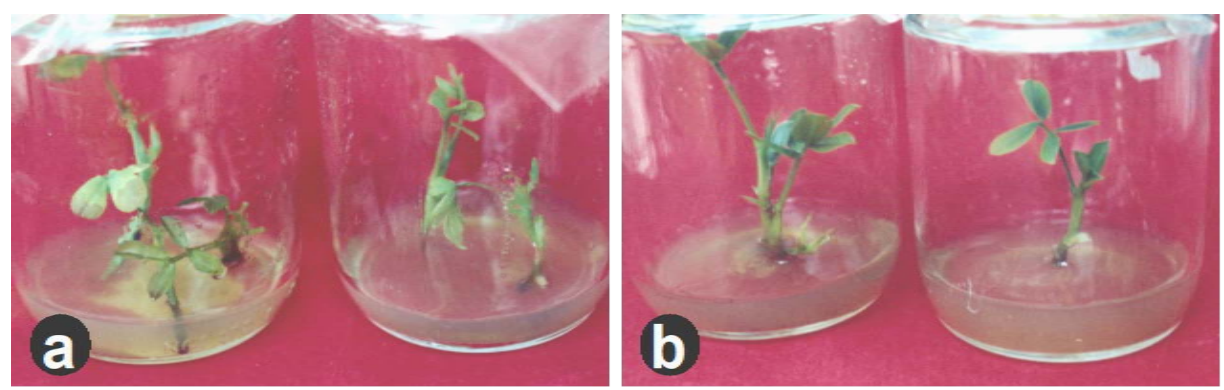

Gambar 3. Contoh respons tunas R0 kacang tanah yang diregenerasikan (a) dari embrio somatik (ES) tanpa seleksi in vitro dan (b) dari ES hasil seleksi in vitro yang insensitif terhadap filtrat kultur cendawan Sclerotium rolfsii. Daun dari tunas R0 tanpa seleksi in vitro dalam medium selektif menunjukkan klorosis (menguning), sedangkan tunas R0 hasil seleksi in vitro mampu tumbuh normal dalam medium selektif.

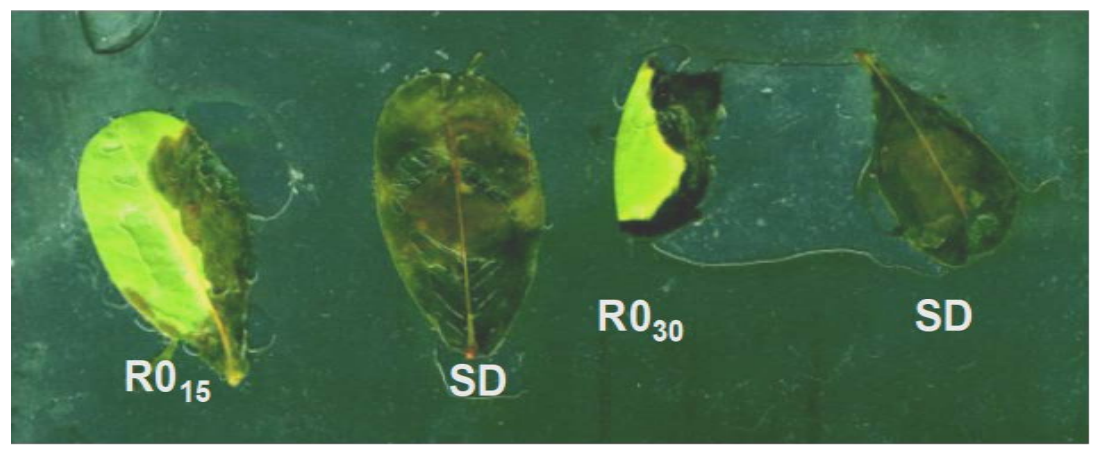

Gambar 4. Contoh respons jaringan leaflet kacang tanah tanaman awal dan tanaman R0 hasil seleksi in vitro terhadap infeksi Sclerotium rolfsii dengan metode detached-leaf test secara semi in vitro. SD = leaflet dari tanaman kacang tanah cv. Kelinci awal yang tidak melalui seleksi in vitro, $\mathrm{R}_{15}=$ Galur tanaman nomor 15 - dengan tingkat kerusakan 40\%, dan $\mathrm{R}_{30}=$ Galur tanaman nomor 30 - dengan tingkat kerusakan 60\%.

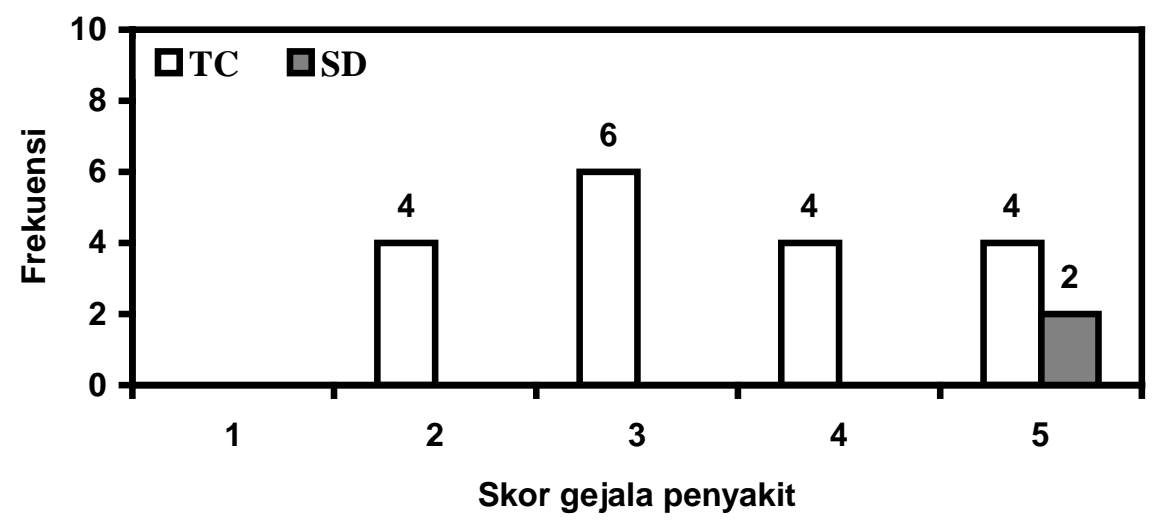

Gambar 5. Pengelompokan dan frekuensi tanaman R1 zuriat galur R0 yang diregenerasikan dari ES hasil seleksi in vitro yang insensitif terhadap filtrat kultur cendawan (TC) dan tanaman kacang tanah awal yang tidak melalui seleksi in vitro (SD) berdasarkan skor gejala penyakit yang terjadi setelah diinokulasi. 
Tabel 2. Respons jaringan daun sejumlah galur tanaman R0 yang diregenerasikan dari embrio somatik hasil seleksi in vitro (SC) terhadap infeksi Sclerotium rolfsii dengan metode detached leaf test secara semi in vitro.

\begin{tabular}{|c|c|c|}
\hline $\begin{array}{l}\text { Nomor galur } \\
\text { Tanaman R0 }\end{array}$ & $\begin{array}{l}\text { Persentase daun dan anak daun yang } \\
\text { mengalami nekrosis }(\%)^{*}\end{array}$ & $\begin{array}{l}\text { Produksi benih } \\
\text { dari tanaman R0** }\end{array}$ \\
\hline K1-SC & 100 & + \\
\hline K5-SC & 100 & + \\
\hline K6-SC & 100 & + \\
\hline K7-SC & 100 & + \\
\hline K10-SC & 100 & + \\
\hline K11-SC & 70 & + \\
\hline K13-SC & 100 & + \\
\hline K14-SC & 100 & + \\
\hline K15-SC & 40 & + \\
\hline K17-SC & 100 & + \\
\hline K18-SC & 100 & + \\
\hline K19-SC & 80 & + \\
\hline K20-SC & 60 & + \\
\hline K21-SC & 100 & + \\
\hline K24-SC & 100 & + \\
\hline K25-SC & 60 & + \\
\hline K30-SC & 60 & - \\
\hline K34-SC & 60 & - \\
\hline K35-SC & 100 & - \\
\hline K36-SC & 100 & - \\
\hline K37-SC & 100 & - \\
\hline R038-SC & 100 & - \\
\hline R039-SC & 100 & - \\
\hline $\mathrm{K}-\mathrm{SD}^{* * *}$ & 100 & + \\
\hline
\end{tabular}

* Berdasarkan hasil inokulasi dengan metode detached leaf test, persentase dihitung berdasarkan luasan anak daun yang nekrosis dibandingkan dengan anak daun awal.

** Galur R0 yang ditanam di rumah plastik mampu (+) atau tidak mampu (-) menghasilkan polong kacang tanah dengan biji yang viabel.

*** Benih kacang tanah cv. Kelinci - awal yang tidak melalui proses seleksi in vitro. 
Tabel 3. Respons sejumlah galur tanaman R1 zuriat dari tanaman R0 yang diregenerasikan dari embrio somatik hasil seleksi in vitro terhadap infeksi Sclerotium rolfsii di rumah plastik.

\begin{tabular}{|c|c|c|c|}
\hline No. galur tanaman R1 & $\begin{array}{l}\text { Respons setelah inokulasi } \\
\text { 1) }\end{array}$ & Skor gejala penyakit & $\begin{array}{l}\text { Produksi benih dari tanaman } \\
\mathrm{R} 1^{3)}\end{array}$ \\
\hline K1.11-SC & $\mathrm{H}$ & 3 & + \\
\hline K1.14-SC & $\mathrm{H}$ & 2 & + \\
\hline K1.15-SC & M & 5 & - \\
\hline K3.1-SC & $\mathrm{H}$ & 2 & + \\
\hline K3.10-SC & $\mathrm{H}$ & 3 & + \\
\hline K3.12-SC & $\mathrm{H}$ & 3 & + \\
\hline K5.4-SC & M & 5 & - \\
\hline K5.7-SC & $\mathrm{H}$ & 2 & + \\
\hline K5.14-SC & M & 5 & - \\
\hline K10.5-SC & $\mathrm{H}$ & 4 & - \\
\hline K10.11-SC & $\mathrm{H}$ & 4 & - \\
\hline K10.12-SC & $\mathrm{H}$ & 3 & + \\
\hline K13.13-SC & $\mathrm{H}$ & 3 & + \\
\hline K13-14-SC & M & 5 & - \\
\hline K13-115SC & $\mathrm{H}$ & 4 & - \\
\hline K26.8-SC & $\mathrm{H}$ & 3 & + \\
\hline K26.15-SC & $\mathrm{H}$ & 2 & + \\
\hline K26.20-SC & $\mathrm{H}$ & 4 & - \\
\hline $\mathrm{K}-\mathrm{SD}^{4)}$ & M & 5 & - \\
\hline K-SD ${ }^{4)}$ & M & 5 & - \\
\hline
\end{tabular}

Keterangan: ${ }^{1)} \mathrm{H}=$ hidup dan $\mathrm{M}=$ mati sesudah diinokulasi dengan cendawan Sclerotium rolfsii di rumah plastik. ${ }^{2)}$ Skor $0=$ tanaman tidak bergejala, Skor $1=$ gejala nekrosis dengan luasan hingga 0.5 lingkar batang, skor 2= gejala nekrosis dengan luasan antara 0.5-0.75 lingkar batang, skor3=gejala nekrosis telah melingkari seluruh lingkar batang, bercak cokelat meluas dan kulit batang kadang-kadang sobek, skor 4= seperti skor 3, batang yang terserang mulai terkulai dan sebagian daun layu, skor5=tanaman mati. ${ }^{3)}$ Galur R0 yang ditanam di rumah plastik mampu (+) atau tidak mampu (-) menghasilkan polong kacang tanah dengan biji yang viabel. ${ }^{4)}$ Benih kacang tanah cv. Kelinci - awal yang tidak melalui proses seleksi in vitro. 


\section{PEMBAHASAN}

Salah satu keuntungan terpenting teknik seleksi in vitro adalah teknik ini memungkinkan diseleksinya fenotipe unggul dari sejumlah besar populasi sel yang secara fisiologi seragam, pada kondisi yang terkontrol, dalam waktu singkat dan tidak memakan tempat. Namun demikian, ada beberapa kekurangan dari penggunaan teknik ini, yaitu cukup besar kemungkinan didapatkan perubahan genetika tanaman yang tidak diinginkan selama proses seleksi seiring dengan bertambah lamanya pengulturan sel in vitro (Hammerschlag 1992; Skirvin et al. 1994). Di samping itu, diperlukan beberapa generasi sejak dilakukan seleksi in vitro untuk dapat mengetahui adanya varian somaklonal yang bersifat unggul dan stabil. Amberger et al. (1992) melakukan analisis keberadaan dan kestabilan varian somaklonal yang terjadi akibat kultur in vitro kedelai pada generasi R0, R1, R2, R3 dan R4, sedangkan Jin et al. (1997) melakukan penapisan untuk resistensi terhadap infeksi Fusarium solani pada kedelai hasil seleksi in vitro pada generasi R1 dan R2. Oleh karena itu, metode identifikasi dini untuk varian yang toleran terhadap patogen target yang dilakukan pada generasi R0 akan sangat membantu pendugaan didapatkannya zuriat somaklon yang toleran atau resisten penyakit dalam suatu program pemuliaan tanaman yang menggunakan kultur sel dan jaringan tanaman dengan seleksi in vitro.

Dalam percobaan ini, uji respons tunas R0 terhadap 30\% FK S.rolfsii mengakibatkan sebanyak 15 dari 19 (79\%) tunas R0 yang diuji mempunyai skor kerusakan $(\mathrm{SK})=1$ (tunas sehat, tidak berakar), yang mengindikasikan insensitivitas terhadap agens penyeleksi. Di lain pihak, 8 dari 9 tunas yang tidak melalui seleksi in vitro, ketika diuji respons-nya terhadap 30\% FK cendawan menghasilkan SK=3 (pucuk tunas mulai mati), yang mengindikasikan sensitivitas terhadap agens penyeleksi. Hasil tersebut konsisten dengan percobaan inokulasi $S$. rolfsii terhadap tanaman R1 di rumah plastik, yaitu bahwa 14 dari 18 (78\%) tanaman R1 yang diinokulasi dengan S.rolfsii masih hidup dengan frekuensi skor gejala penyakit: skor 2 sebanyak 4 tanaman, skor 3 sebanyak 6 tanaman dan skor 4 sebanyak 4 tanaman. Tanaman awal cv. Kelinci yang tidak melalui seleksi in vitro yang diinokulasi semuanya menghasilkan skor 5 atau mati. Dengan demikian, pengujian respons tunas R0 terhadap FK $S$. rolfsii tampaknya dapat digunakan sebagai identifikasi dini untuk varian somaklonal kacang tanah hasil seleksi in vitro yang toleran terhadap infeksi $S$. rolfsii.

Hasil percobaan dengan detached leaf test menunjukkan bahwa 70\% (16 dari 23) dari tanaman R0 yang diuji mengalami nekrosis total, dan hanya 30\% (7 dari 23) tanaman R0 yang diuji mengalami nekrosis parsial. Hasil pengamatan juga menunjukkan bahwa baik nomor-nomor yang mengalami nekrosis total atau parsial pada detached leaf test tersebut, ternyata semuanya menghasilkan zuriat R1 yang bersegregasi antara hidup $(\mathrm{H})$ dengan skor 2-4 dan mati (M) atau skor 5. Dengan kata lain, berdasarkan metode detached leaf test ini tidak terdapat korelasi antara hasil pengujian pada generasi R0 dan generasi R1, sehingga metode ini tidak dapat digunakan sebagai identifikasi dini untuk varian somaklonal kacang tanah yang toleran $S$. rolfsii.

Dalam teknik seleksi in vitro kalus embriogenik dengan agens penyeleksi FK cendawan yang telah dikembangkan sebelumnya (Yusnita et al. 2005), kemungkinan besar hanya sel-sel atau jaringan yang berfenotipe insensitif terhadap agens penyeleksi dan bersinggungan dengan FK cendawan saja yang masih hidup, sedangkan sebagian besar sel atau jaringan yang sensitif mencokelat dan mati. Akan tetapi karena kalus embriogenik kacang tanah yang diseleksi berupa clump yang pada proses seleksi in vitro selalu bersinggungan dengan agens penyeleksi, maka ada kemungkinan bahwa sebagian kecil sel dari kalus embriogenik tersebut yang terletak di dalam clump dan tidak secara langsung bersinggungan dengan agens penyeleksi telah tumbuh menjadi jaringan di dalam embrio somatik (ES) yang merupakan kimera antara yang insensitif dan yang sensitif terhadap agens penyeleksi. Embrio somatik kimera dengan sebagian sel-nya sensitif sedangkan sebagian besar sel yang lain insensitif terhadap FK cendawan tersebut, pada tingkat planlet atau tunas R0 kemungkinan besar masih bersifat insensitif terhadap FK cendawan, sedangkan pada level tanaman utuh di rumah plastik diduga mempunyai jaringan daun yang rentan infeksi S.rolfsii pada porsi yang lebih banyak dibandingkan ketika masih berupa tunas R0. Namun demikian, tanaman R0 kimera tersebut selalu mempunyai peluang untuk menghasilkan tanaman zuriat yang bersegregasi antara yang resisten dan yang rentan terhadap infeksi $S$. rolfsii, karena sebagian sel atau jaringannya berasal dari sel-sel yang insensitif, sedangkan sebagian sel yang lain mungkin sensitif terhadap agens penyeleksi. Hal ini didukung oleh hasil pengamatan bahwa dari ke-18 tanaman R1 yang 
merupakan zuriat dari 6 galur R0 yang diinokulasi $S$. rolfsii di rumah plastik, zuriat 3 galur R0 bersegregasi antara tanaman yang masih hidup (menghasilkan biji viabel) dan yang mati akibat infeksi patogen tersebut, sedangkan zuriat 3 galur R0 lainnya hidup semua.

Karena kondisi seleksi in vitro yang dikembangkan tersebut menyebabkan kemungkinan terbesar sel-sel atau jaringan yang insensitif terhadap agens penyeleksi saja yang hidup, sedangkan sebagian besar sel atau jaringan yang sensitif mencokelat dan mati, maka fenotipe insensitivitas terhadap FK cendawan pada ES hasil seleksi in vitro diduga disebabkan oleh mutasi pada sel-sel kalus embriogenik yang dikendalikan oleh satu gen dominan $\left(\mathrm{R}^{*} \mathrm{r}\right)$ atau kemungkinan yang lebih kecil karena adanya double dominan mutant $\left(\mathrm{R}^{*} \mathrm{R}^{*}\right)$ dari sel eksplan kacang tanah awal yang sensitif (rr). Hal ini lah yang memungkinkan identifikasi untuk sifat toleran atau resisten terhadap $S$. rolfsii dapat dilakukan secara dini pada generasi R0, dalam hal ini dengan menguji respons tunas R0 hasil seleksi in vitro terhadap 30\% FK cendawan.

Tujuan akhir dari penelitian ini adalah untuk mendapatkan varian somaklon yang resisten atau toleran terhadap penyakit busuk batang Sclerotium. Beberapa peneliti terdahulu telah mendemonstrasikan bahwa resistensi terhadap suatu penyakit berkorelasi positif dengan resistensinya terhadap toksin yang dikeluarkan oleh patogen (Byther dan Steiner 1972, Gengenbach et al. 1978, Gentile et al. 1993, Jayasankar et al. 2000). Walaupun tidak dilakukan analisis kandungan metabolitnya, namun filtrat kultur S. rolfsii yang digunakan dalam penelitian ini adalah agens penyeleksi yang sama dengan yang digunakan pada percobaan sebelumnya (Yusnita et al. 2005), dan diasumsikan mengandung toksin asam oksalat, sebagaimana dilaporkan oleh Stone dan Armentout (1985). Dalam proses infeksinya, S. rolfsii mengeluarkan sejumlah besar asam oksalat dan enzim endo-poligalakturonase yang beraksi secara sinergistik untuk mematikan jaringan tanaman inang (Punja et al 1985, Punja 1985). Dalam percobaan ini, penggunaan agens penyeleksi berupa FK cendawan yang telah disterilkan, yang diasumsikan mengandung toksin asam oksalat tetapi tidak lagi mengandung enzim pendegradasi dinding sel, kemungkinan telah dapat mengurangi terjadinya kerusakan jaringan inang karena insensitivitas jaringan SE terhadap filtrat kultur cendawan, sedangkan kerusakan jaringan akibat enzim pendegradasi dinding sel tidak dapat dicegah. Oleh karena itu, sejumlah tanaman R1 yang diinokulasi masih menunjukkan gejala penyakit berupa lesio dengan skor 2-3, akan tetapi dalam perkembangan infeksinya tanaman hasil seleksi in vitro tersebut masih tetap hidup dan menghasilkan benih viabel, sedangkan tanaman awal yang tidak melalui tahapan seleksi in vitro semuanya mati dengan skor 5 .

Hasil penelitian ini telah menunjukkan bawa pengulturan tunas R0 dalam media selektif berisi 30\% FK cendawan dapat digunakan sebagai identifikasi dini galur kacang tanah yang toleran terhadap infeksi S. rolfsii hasil seleksi in vitro dengan FK cendawan. Walaupun demikian, pengujian resistensi terhadap S. rolfsii perlu dilakukan terhadap varian somaklonal pada generasi selanjutnya (R2) untuk mempelajari apakah karakter tersebut secara konsisten mewaris dan stabil, sekaligus untuk menyeleksi karakter agronomi unggul yang lain.

\section{DAFTAR PUSTAKA}

Ahmed KZ, Mesterhazy A, Bartok T \& Sagi F. 1996. In vitro techniques for selecting wheat (Triticum aestivum L.) for Fusarium-resistance. II. Culture filtrate technique and inheritance of Fusarium-resistance in the somaclones. Euphytica 91:341-349.

Amberger LA, Palmer RG \& Shoemaker RC. 1992. Analysis of culture-induced variation in soybean. Crop Sci 32:1103-1108.

Byther RS \& Steiner GW. 1972. Use of helminthosporoside to select sugarcane seedlings resistant to eye spot disease. Phytopatol 62:466-470.

Gamborg OL, Miller RA \& Ojima K. 1968. Nutrient requirement of suspension cultures of soybean root cells. Exp Cell Res 50:151-158.

Gengenbach BG, Green CE \& Donovan CM.1978. Inheritance of selected pathotoxin resistance in maize plants regenerated from cell cultures. Proc Natl Acad Sci 74:5113-5117.

Gentile A, Tribulato E, Deng ZN, Galun E, Fluhr R \& Vardi A. 1993. Nucellar callus of 'Feminello' lemon, selected for tolerance to Phoma tracheiphila toxin, shows enhanced release of chitinase and glucanase into the culture 
medium. Theor Appl Genet 86:527-532.

Hammerschlag FA. 1992. Somaclonal variation. In: Hammerschlag FA \& Litz RE (ed). Biotechnology of Perennial Fruit Crops. Walingford: CAB International. p 35-55.

Jayasankar S, Li Z \& Gray DJ. 2000. In vitro selection of Vitis vinifera 'Chardonay' with Elsinoe ampelina culture filtrate is accompanied by fungal resistance and enhanced secretion of chitinase. Planta 211:200-208.

Jin H, Hartman GL, Huang YH, Nickell CD \& Widholm JM. 1996. Regeneration of soybean plants from embryogenic suspension cultures treated with toxic culture filtrate of Fusarium solani and screening of regeneraants for resistance. Phytopathol 86:714-718.

Murashige T \& Skoog F. 1962. A revised medium for rapid growth and bioassays with tobacco tissue cultures. Physiol Plant 15:473-497.

Pratt RG. 1996. Screening for resistance to Sclerotinia trifoliarum in alfalfa by inoculation of excised leaf tissue. Phytopathol 86:923-928.
Punja ZK. 1985. The biology, ecology and control of S. rolfsii. Ann Rev Phytopathol 23:124-135.

Punja ZK, Huang JS \& Jenkins SF. 1985. Relationship of mycelial growth and production of oxalic acid and cell wall degrading enzymes to virulence in Sclerotium rolfsii. Can J Plant Pathol 7: 109-117.

Skirvin RM, McPheeters KD \& Norton M. 1994. Sources and frequency of somaclonal variation. HortScience 29:1232-11237.

Song HS, Lim SM \& Widholm JM. 1994. Selection and regeneration of soybean resistant to pathotoxic culture filtrate of Septoria glycines. Phytopathol 84:948-951.

Stone HE \& Armetrout VN. 1985. Production of oxalic acid by Sclerotium cepivorum during infection of onion. Ecologia 11:526-530.

Yusnita \& Sudarsono. 2004. Inoculation methods and reactions of 30 peanut genotypes to Sclerotium stem rot disease due to Sclerotium rolfsii Sacc. Hayati 11:53-58.

Yusnita, Widodo \& Sudarsono. 2005. In vitro selection of peanut somatic embryos on medium containing culture filtrate of Sclerotium rolfsii and plantlet regeneration. Hayati 12:50-56. 